\title{
Marketing Plan Competition For Experiential Learning
}

Emin Civi, PhD, University of New Brunswick, Saint John, Canada

Elif S. Persinger, PhD, Eastern Michigan University, USA

\begin{abstract}
Many students find traditional lectures, routine memorization, and restatement of facts and terms tedious and boring (Munoz and Huser, 2008). This requires professors to employ a variety of teaching techniques, for example, live case classroom projects. Such an experiential learning opportunity encourages students to become involved with the materials they are attempting to learn by requiring them to apply theory to real-life situations where ambiguity, change, and risk exist (Lewis and Williams, 1994). This paper presents an assessment of a semester long marketing plan competition, which was incorporated into the Marketing Management Course. The competition required all student teams to deal with the assigned client and compete with each other to produce the winning marketing plan. Student feedbacks indicated they enjoyed the experiential learning opportunity and the competition format.
\end{abstract}

Keywords: Experiential Learning; Live Cases; Class Competition; Classroom Projects; Marketing Plan

\section{INTRODUCTION}

C n recent years, undergraduate education has increasingly become more student-centered where teachercentered lecture format is at least supplemented, if not replaced, by experiential learning (Lamount and Friedman, 1997). Today's college students are demanding to be involved in their learning experiences. They find one-way lectures, routine memorization, and restatement of facts and terms tedious and boring (Munoz and Huser, 2008). According to Shakarian (1995) traditional lecture-based classes facilitate the process of passive learning. Students spend their class time recording the content and are left little time to reflect, synthesize, and apply the concepts discussed. Recently, several researchers have questioned whether traditional pedagogical methods, such as lecture, are truly beneficial to students' education (Bringle and Hatcher, 2003). Guyton (2000) views traditional pedagogical methods as being responsible for turning students into passive underachievers. Gupta, Burns and Schifer (2010) echo Bransford and Vye's (1989) concern about the "inert knowledge problem" - a situation where students possess a significant amount of knowledge but are unable to apply that knowledge to real world problems or to make the transition from memory to action. Hence, interest in more active and experiential learning pedagogies has increased significantly (Barr and Tagg, 1995 Young 2002; Elam and Spotts, 2004; Gupta, Burns and Schifer, 2010).

According to the active learning paradigm, instructors should be designers of a learning environment in which students are active participants in the learning process (Camarero, Rodríguez and San José, 2009). Active learning techniques (both non-experiential and experiential) aim to elicit student involvement with the materials they are attempting to learn by encouraging them to apply theory dynamically to real-life situations. Non-experiential techniques encourage the students to actively process the course materials whereas experiential techniques provide students with the opportunity to go beyond conceptual discussion by applying their theoretical knowledge in specific real-world contexts (Hamer 2000). The value created for students by using active learning techniques such as role plays, case studies, games, simulations, projects etc. in the classroom is well established in the marketing pedagogy literature (Drea, Tripp and Stuenkel, 2005; Smith and Van Doran, 2004; Kennedy, Lawton and Walker, 2001, Wright, Bitner, and Zeithaml, 1994). 
Students appear to appreciate the benefits of the active learning approach as many studies have documented high student satisfaction ratings on various active learning techniques (Vander Schee, 2009; Yamarik, 2007; Laverie, 2006). Professors also find them meaningful as they allow students to take more ownership over their learning and do not let students simply record and then replicate static information. Integration of course material with dynamic exercises in active learning helps students to better understand course content and improve academic performance (Drea, Tripp, and Stuenkel, 2005).

In this study, an example of experiential learning within the context of an undergraduate capstone Marketing Management course in a Canadian university will be described.

\section{EXPERIENTIAL LEARNING}

Experiential learning represents an effective learning resulting from active student involvement with an experience and subsequent reflection on that experience (Kolb, 1984; Gentry, 1990; Frontczak and Kelley, 2000, Elam and Spotts, 2004). It requires that the professor allows greater student control over their own learning in terms of both content and speed of acquisition. Experiential learning techniques encourage students to become involved with the materials they are attempting to learn by requiring them to apply theory to real-life situations where ambiguity, change, and risk exist (Lewis and Williams, 1994).

Several important skills can be acquired through experiential learning that may not be well developed in more traditional, passive learning environments such as lectures only (Elam and Spotts, 2004). Development and revision of time lines and project management are examples of skills that are best learned by doing, rather than by simply reading about them (Elam and Spotts, 2004; Darian and Coopersmith, 2001). Actively assessing the communication and participation of self and others, including giving peers constructive criticism, are difficult skills for most professionals, and skills that most undergraduates may not even practice (Dyrud, 2001; Peterson, 2001) unless they are exposed to an experiential learning opportunity. In addition, faculty would like to encourage development of critical thinking and problem-solving skills among their students, which experiential learning techniques appear to foster (Kennedy, Lawton, and Walker, 2001).

In addition, experiential activities increase not only student motivation but also long-term retention (Coleman, 1995, Toncar and Cudmore, 2000). Wynd (1989) also states that "teaching methods that actively engage students in the learning process enhance student learning and development". Similarly, Gaidis and Andrews (1990) recommend that students learn better when they are actively involved with concrete experiences. Experiential techniques can also be designed to improve skills in the areas of decision making, problem solving, planning, written and oral communication, and creativity. The development of these skills should be a focus of undergraduate business programs, as students graduating with business degrees need these skills to be successful in the marketplace (Bobbitt et al., 2000).

\section{EXPERIENTIAL LEARNING IN MARKETING EDUCATION}

There have been a strong criticism toward business educators that they are not preparing students to deal with real world problems even though they possess a significant amount of knowledge to do so (Candy and Crebert, 1991; Bransford and Vye 1989). Traditional pedagogical methods are seen responsible for turning students into "passive underachievers" (Guyton, 2000). However, business educators have started using experiential learning methods long before the "experiential learning" label was popularized in the psychological and educational literature (Elam and Spotts, 2004). As early as 1909, Doc Copeland introduced realism into the classroom with the case method of teaching at Harvard Business School. The use of cases has grown to be a popular method of management teaching. Another innovation in experiential learning methods was the introduction of computerized simulations in the 1970s (Chiesl, 1990).

The marketing literature also indicates that, in the last two decades, marketing educators have broadly embraced experiential learning methods as a way to help students learn marketing techniques (e.g., Graeff, 1997; Titus and Petroshius, 1993; Williams, Beard and Rymer, 1991). Experiential learning through case studies, projects, etc. increases the level of realism (de los Santos and Jensen, 1985) and learning involvement (Sautter, Pratt, and 
Shanahan, 2000), encourages higher order thinking (Bonwell and Eison, 1991), leads to improved test performance (Hakeem, 2001; Hamer, 2000) and fosters an appreciation of marketing among non-marketing majors (Henke, 1985).

Camarero, Rodríguez and San José (2009) indicate in their study that marketing is a discipline where the application of experiential learning methods is particularly advisable since it is taught as "a process of understanding customer needs and developing a marketing plan that allows market demands to be satisfied and a firm's objectives to be achieved in a profitable manner". This process involves analysing the market and the competition, and making strategic and tactical decisions about the different marketing mix variables. Therefore, the outcomes of the marketing learning process should also include the student initiation into the work activities of marketing managers, such as gathering information, evaluating alternatives and strategic decision-making (Camarero, Rodríguez and San José, 2009). Young (2002) also sees experiential learning as a powerful pedagogy for teaching marketing's broad body of concepts, principles, and analytics by internalizing theory through guided practice.

Experiential learning in Marketing can be through many techniques, including living cases (LeCair and Stottinger, 1999; Cheney, 2001), unstructured or semi-structured class exercises and assignments (Hamer 2000), interactive web based cases (Owen, 1999), field trips (Gremler et al., 2000), integrating practitioners into the course (Linrud and Hall, 1999), solving real business problems with existing organizations (Alon and Cannon 2000; Kennedy, Lawton and Walker, 2001), internet or disk-based simulations (Gruca, 2000), integrated course projects (Bobbitt et al., 2000), client based projects (Lopez and Lee, 2005; Haas and Wotruba, 1990) and internships (Hite and Bellizzi, 1986).

\section{MARKETING PLAN COMPETITION AS EXPERIENTIAL LEARNING}

Generally accepted objectives of a capstone marketing course include integrating the marketing mix and translating marketing concepts into meaningful marketing strategy decisions, providing real life experience with marketing management issues, stimulating creative thinking to come up with innovative solutions to marketing problems and exposing the students to group work and interaction with their peers (Haas and Wotruba,1990). These objectives can be achieved by assigning a class project in the form of a live case study as an experiential learning tool (by itself or along with other methods such as traditional case analyses and simulation games). The point is that the students are faced with a real marketing situation where they will identify, research, analyze and solve the problem. The entire class can be assigned to a single project, divided into competing teams working on the same project or divided into teams working on different projects. What is essential is to choose a marketing problem and a cooperative client (who will provide the live case) that will satisfy the objectives of a capstone marketing course for the students (Kennedy, Lawton and Walker, 2001; Gremler et.al., 2000; Haas and Wotruba, 1990)

Live cases as an experiential learning technique is a powerful tool for making a shift from product-based teaching to process-based teaching (Kennedy, Lawton, and Walker, 2001). In live cases students act as real business consultants. Live cases offer students an opportunity to integrate their academic and work experiences in the creation of a consulting solution for a real problem. They provide an excellent mechanism to improve research abilities and critical thinking skills. Students learn how a specific marketing topic must be evaluated in a real situation and benefit from offering a professional opinion on a real business problem (Camarero, Rodriguez and San Jose, 2009).

Live cases also help course concepts come to life and greatly enhance students' ownership of the learning process (Lopez and Lee, 2005).The opportunity for students to apply their marketing knowledge to the needs of an actual company provides a strong, hands-on learning experience. It fosters skills such as problem solving, critical thinking, communication and teamwork-relevant skills that students need in the workplace (Barr and McNeilly, 2002; Kennedy, Lawton, and Walker, 2001). They also enhance students' motivation and commitment since students know that their recommendations may be used in an actual business context (Fox, 2002). In addition, live cases connect students with the business community (Kennedy, Lawton, and Walker, 2001). Furthermore, as most live cases use student teams, students develop the interpersonal skills required by businesses (Camarero, Rodriguez and San Jose, 2009). 
In the specific case described in this study, a marketing plan competition is used as the experiential learning opportunity for the capstone undergraduate Marketing Management course. The semester, hence the time period for the project, was eight weeks (regular semesters are thirteen weeks). Students formed 6 groups of five students each (Marketing Consultant Teams). Groups competed against each other in designing a marketing plan for one client, the university's main cafeteria (Cafeteria) which is run by a well-known international catering company. The benefits of choosing a client internal to the university extended beyond convenience. Cafeteria was faced with an image problem that required an immediate attention. Hence the manager was very interested in receiving a top-notch marketing plan as a result of the classroom project competition. This, in turn, lead to the client's strong commitment and delivery of data and information along with face-to-face time with students to discuss the business situation and answer questions. As a result, the students understood their tasks well and committed to the project whole heartedly.

The project guidelines for both the students and the client we developed and given to them at the beginning of the semester. For the students, the guidelines included what a marketing plan is and how it is formulated. The project involved the integration of all marketing mix components and development of tactical and strategic actions for the client to take within the one-year period after the completion of the project. Students also were informed that there were going to be an information meeting and follow-up interviews with the manager of the Cafeteria and various stakeholders. These stakeholders include domestic and international college students who live on campus and off campus, high school students who attend weekly workshops at the University (external customers) and faculty, all of which eat at the Cafeteria regularly. These interviewees were recruited by the instructor at the Cafeteria. Each team was required to prepare questions to ask at these meetings and interviews ahead of time. This requirement gave the meetings/interviews more structure; still spontaneous questions could also be asked. There were a total of four in-class meetings/interviews throughout the semester.

For the client, the guidelines included the purpose of the project, timeline (including classroom visits and interviews with student teams) and required information and data. Cafeteria manager also agreed serve as a judge along with the District Manager of the catering company the Cafeteria is under contract with during the final presentations of the competing marketing plans and to provide a \$50 Cafeteria gift certificate for each member of the winning team.

At the end of the semester, all six teams presented their completed projects. Prior to the presentations, written reports of each team's marketing plan were provided to the judges. This allowed them to prepare questions that they could ask during the oral presentations of the projects. The manner in which each team responded the judges' questions and comments was part of the students' experience and contributed to further the goal of providing the students the experiential learning opportunity through the classroom project.

After the presentations were complete, the judges determined the winner of the competition based on the thoroughness of the content, the quality of the tactics/strategies suggested and the ability of the team members to answer the judges' questions in a cohesive manner. The manager of the Cafeteria presented the each member of the winning team with a $\$ 50$ Cafeteria gift certificate as a reward. Also, as a courteous gesture, the Cafeteria manager had food and soft drinks brought from the Cafeteria for the whole class to thank them for their good work.

\section{BENEFITS TO THE STUDENTS}

Class projects provide a combination of visual and auditory presentations while maintaining the integrity of theoretical conceptualizations, simulations and applications (de los Santos and Jensen, 1985). Also, the experiential approach as opposed to lecture format presents the students more intellectual challenges, and fosters more student interest and commitment to the subject (Cohen, 1987). This was reflected in the student comments after the project competition was complete as well. Students expressed that they learned a great deal about the process of preparing a marketing plan and integrating their fragmented marketing knowledge on principles, concepts and theories to create a cohesive and comprehensive document. They felt that this project competition was an effective introduction to the "real world". Working with a client was a valuable experience and the hands-on approach allowed them to gain perspectives that can be useful throughout their careers. The marketing plan competition in the capstone Marketing Management course was their experiential learning component during their university business education which provided the students to do "real" business research and analysis that lead to actionable solutions to real business 
problems. Also, experiential learning enhances the students' professionalism (Nunamaker, 2007) and helps students build a professional network (although limited in scope in the current example) that adds to the quality of their program of education. These, in turn, become an asset that the students can rely on when they are in the job market and throughout their careers.

Students were also mostly pleased by the competition format. Although some expressed that each group working with an individual client would result in more perspectives and original ideas, most thought the competition inspired them to be more committed and involved throughout the semester to learn more and better. This is supportive of the findings of, for example, Stutts and West, 2003; Jansen et al., 2008; Rundle-Thiele and Kuhn, 2008; Zabkar, 2008 who state that students learn more through competitive projects. Some of the student comments are provided in the Appendix section.

\section{BENEFITS TO THE CLIENT}

The first and foremost benefit for the client is that the manager now has one or more high quality marketing plans that reflect the expertise of the instructor and senior level marketing students. Based on the recommendations in these documents the manager can develop new perspectives and business solutions that will benefit the Cafeteria's position in the marketplace. Second, by participating the experiential learning exercise, the client has fostered good relationships with the student body and the faculty member, which is most likely to be shared with peers through word of mouth and raise the Cafeteria's profile within the entire campus.

\section{CONCLUSION}

This classroom project described in this article has ample merit due to the fact that it combines an experiential learning opportunity with competition format. Students had the opportunity to apply their theoretical marketing knowledge which enabled them to see the connections and interaction among the marketing concepts they learned before. They learned about the process of preparing a complete marketing plan, which is a useful competence for them in the marketplace. The fact that they formed teams and competed against each other added to the experience by increasing their motivation and commitment. These benefits were attested in students' comments as well. Some students also said that the live case experience was an eye-opening one and steered them toward marketing as a long-term career choice.

This whole experience was very rewarding for the professors as well. It constituted a research project where we observed how the students' thinking process and approach to the marketing problem presented evolved throughout the semester. It was very gratifying to see the students gain more confidence and satisfaction as they were able to apply their marketing knowledge and come up with solutions that the client is willing to implement. They felt they were making valuable and meaningful contributions. As enablers of the whole process, we were very proud and this added to our job satisfaction significantly.

Having emphasized the positive aspects and benefits of the live case classroom project, we also need to point out some limitations and lessons learned. It can be argued that clients external to the university may present richer "real world" challenges. Researchers should be proactive to find such clients, particularly when the time period for the project is limited to 8-12 weeks. All parties involved should come to a clear understanding regarding the expectations and responsibilities of the client, the researchers and the students at the beginning of the project. The benefits of such a project for the client and the students should also be made known clearly to foster cooperation. There should be regular communication to ensure information and data are provided for the project in a timely manner, each party's questions are answered thoroughly throughout the semester.

As for the interviewees who are invited to the classroom to share their experiences with the client, the researchers need to recruit them with care to make sure they are willing and able to explain their interaction with the client in a useful manner to the students. To this end, the researchers should give them a list of possible questions that they can prepare answers for ahead of time. Also, the students should be trained to ask informed questions in order to maximize the efficiency and effectiveness of the interview sessions. 
A classroom project such as the one described in this paper demands dedication and takes a lot of time for preparation, guiding the students and the client, grading, etc. The instructors involved in this project were not compensated for the extra time and effort it took to execute this project. While these type of efforts are encouraged by accrediting organizations and the universities and receives a "pat on the back" from the institution, the reality is that the teaching load structure used at many institutions is not a framework that easily accommodates such projects (Elam and Spotts, 2004). As the classroom project extends the time spent on teaching, time that can be dedicated for other scholarly activities decreases and this might bring negative consequences for the instructor, especially in a research more than teaching oriented institution. However, it is also possible that the project might open doors to other collaborations with the surrounding business community which in turn might benefit the instructor's research agenda down the road. Regardless of the challenges, this classroom project has been a most satisfying experience for both the instructors and the students.

\section{AUTHOR INFORMATION}

Emin Civi is an Associate Professor of Marketing at University of New Brunswick, Saint John, Canada. He obtained his PhD degree from Celal Bayar University in Manisa, Turkey. He has authored/coauthored numerous journal articles and conference papers in international marketing, marketing, and international business areas. E-mail: ecivi@unb.ca

Elif S. Persinger is an Associate Professor of Marketing at the Eastern University of Michigan. She has received her PhD degree from Michigan State University. Her research interests include systems thinking approach to international business education, marketing strategy and diffusion of innovations. She teaches international business, international marketing at both undergraduate and graduate levels. E-mail: esonmez@emich.edu

\section{REFERENCES}

1. Alon, I., and N. Cannon (2000), "Internet-based experiential learning in international marketing: The case of Globalview.org", Online Information Review, 24 (5), 349-56.

2. Barr, R. B. And J. Tagg (1995), "From teaching to learning: A new paradigm for undergraduate education" Change, 27(6), 12-25.

3. Bobbitt, L. M., S. A. Inks, K. J. Kemp, D. T. Mayo(2000), "Integrating marketing courses to enhance teambased experiential learning", Journal of Marketing Education, 22, 15-24.

4. Bonwell, C. C., J. A. Eison (1991), Active learning: Creating excitement in the classroom (ASHE-ERIC Higher Education Report No. 1), Washington, DC: George Washington University, School of Education and Human Development.

5. Bransford, J. D. and N. J. Vye (1989), “A perspective on cognitive research and its implications for instruction”, In L. Resnick and L. E. Klopfer (Eds.), Toward the Thinking Curriculum: Current Cognitive Research (175-205). Alexandria, VA: Association for Supervision and Curriculum Development.

6. Bringle, R. G. and Hatcher, J. A. (2003), Reflection in service learning: Making meaning of experience. In S. Jones (Ed.), Introduction to Service Learning Toolkit: Readings and Resources for Faculty. Providence, RI: Campus Compact.

7. Camarero, C., J. Rodríguez and R. San José (2009) “A comparison of the learning effectiveness of live cases and classroom projects", International Journal of Management Education, 8(3), 13-21.

8. Candy, P. and R. G. Crebert (1991), "Ivory tower to concrete jungle", Journal of Higher Education, 62(5), 570-592.

9. Cheney, R. S. (2001), "Intercultural business communication, international students, and experiential learning", Business Communication Quarterly, 64 (December), 90-104.

10. Chiesl, N. E. (1990), "Interactive real time simulation,” In Guide to business gaming and experiential learning, edited by James Gentry, London: Nichols/GP Publishing, 141-58.

11. Coleman, James S. (1995), "Experiential learning and information assimilation: toward an appropriate mix," in The Theory of Experiential Education, K. Warren, M. Sakofs and J. Hunt, eds., Dubuque, Iowa: Kendall-Hunt Publishing Company, 123-129.

12. Darian, J. C., and L. Coopersmith (2001), "Integrated marketing and operations team projects: Learning the importance of cross-functional cooperation", Journal of Marketing Education 23 (August), 128-35. 
13. de los Santos, G., and Jensen, T. D. (1985), "Client sponsored projects: Bridging the gap between theory and practice", Journal of Marketing Education, 7, 45-50.

14. Drea, J. T., C. Tripp and K. Stuenkel (2005), "An assessment of the effectiveness of an in-class game on marketing students' perceptions and learning outcomes", Marketing Education Review, 15(1), 25-33.

15. Dyrud, M. A. (2001), "Group projects and peer review" "Business Communication Quarterly", 64 (December), 106-112.

16. Elam, E. L. R., and H. E. Spotts (2004), “Achieving marketing curriculum integration: A live case study approach", Journal of Marketing Education, 26, 50-65.

17. Feldman, T. B. and K. M. McNeilly (2002), "The value of students' classroom experiences from the eyes of the recruiter: information, implications, and recommendations for marketing educators," Journal of Marketing Education 24(2), 168-73.

18. Fox, T. L. (2002), "A case analysis of real-world systems development experiences of CIS students", Journal of Information Systems Education, 13 (4), 343-50.

19. Frontczak, N. T., and C. A. Kelley (2000), "Special issue on experiential learning in marketing education", Journal of Marketing Education, 22, 3-4.

20. Gaidis, W. and J. C. Andrews (1990), “An experiential approach for integrating ethical analysis into marketing coursework", Journal of Marketing Education, 12 (Summer), 3-9.

21. Gentry, J. W. (1990). What is experiential learning? In J. W. Gentry (Ed.), Guide to business gaining and experiential learning (9-20). London: Kogan Page.

22. Gremler, D. D., K. D. Hoffman, S. M. Keaveney, and L. K. Wright (2000). "Experiential learning exercises in services marketing courses", Journal of Marketing Education 22 (April), 35-44.

23. Gruca, T. S. (2000), "The IEM movie box office market: Integrating marketing and finance using electronic markets", Journal of Marketing Education 22 (April), 5-14.

24. Gupta, Pola B., D. J. Burns and J. Schiferl (2010), "An exploration of student satisfaction with internship experiences in marketing," Business Education and Accreditation, 2(1), 27-37.

25. Guyton, Edith (2000), Social justice in teacher education. The Educational Forum, 64, 108-114.

26. Hakeem, S. A. (2001), "Effect of experiential learning in business statistics" Journal of Education for Business, 77, 95-98.

27. Hamer, L. O. (2000), "The additive effects of semi-structured classroom activities on student learning: An application of classroom-based experiential learning techniques", Journal of Marketing Education, 22, 2534.

28. Henke, J. W. (1985), "Bringing reality to the introductory marketing student" Journal of Marketing Education, 7, 59-71.

29. Hite, R. and J. Bellizzi (1986), "Students expectations regarding collegiate internship programs in marketing", Journal of Marketing Education, 8(3), 41-49.

30. Kennedy, E. J., L. Lawton and E. Walker (2001), "The case for using live cases: Shifting the paradigm in marketing education", Journal of Marketing Education, 23 (August), 145-51.

31. Kolb, D. A. (1984), Experiential learning: Experience as the source of learning and development. Englewood Cliffs, NJ:Prentice Hall.

32. Lamont, L. M., and K. Friedman (1997), "Meeting the challenges to undergraduate marketing education", Journal of Marketing Education, 19 (Fall), 17-30.

33. Laverie, D. A. (2006), "In-class active cooperative learning: A way to build knowledge and skills in marketing courses," Marketing Education Review, 16(2), 59-76.

34. LeCair, D. T. and B. Stottinger (1999), "Using an Intensive Living Case in Graduate Marketing Courses: Experiences from an International Project," Marketing Education Review, 9(3), 31-40.

35. Lewis, Linda H. and Carol J. Williams (1994), "Experiential learning: past and present," in Experiential Learning: A New Approach, Lewis Jackson and Rosemary S. Caffarella (eds.), San Francisco: Jossey-Bass, 5-16.

36. $\quad$ Linrud, J. K. and M. C. Hall, (1999), "Integrating the Business Practitioner into Marketing Coursework," Marketing Education Review, 9(2), 15-22.

37. Lopez, T. B. and R. G. Lee(2005), "Five Principles for Workable Client-Based Projects: Lessons from the Trenches," Journal of Marketing Education, 27 (2), August 2005, 172-188.

38. Millis, B. J., and P. G. Cottell Jr. (1998), Cooperative learning for higher education faculty. American Council on Education Series on Higher Education. Phoenix, AZ: Oryx. 
39. Munoz, C., and Huser, A. (2008). "Experiential and cooperative learning: using a situation analysis project in principles of marketing", Journal of Education for Business, 83(4), 214-220.

40. Nunamaker, T.D. (2007), "Employers and student candidates: How they see each other" NACE Journal, LXVII (4), May, 26-31.

41. Owen, R. S. (1999), "Using programmed branching to automate interactive cases on the web," Marketing Education Review, 9(3), 41-60.

42. Peterson, R. M. (2001), "Course participation: An active learning approach employing student documentation", Journal of Marketing Education 23 (December), 187-94.

43. Sautter, E. T., Pratt, E. R., and Shanahan, K. J. (2000), "The marketing Webquest: An Internet based experiential learning tool”, Marketing Education Review, 10, 47-55.

44. Shakarian, D. C. (1995), "Beyond lecture: Active learning strategies that work", Journal of Physical Education, Recreation, and Dance, 66, 21-24.

45. Smith, L. W. and D. C. Van Doren (2004), "The reality based learning method: A simple method for keeping teaching activities relevant and effective” Journal of Marketing Education, 26(1), 66-74.

46. Titus, P. A. and S. M. Petroshius(1993), "Bringing consumer behavior to the workbench: An experiential approach," Journal of Marketing Education 15(Spring), 20-30.

47. Toncar, M. F. and B. V. Cudmore (2000), "The overseas internship experience", Journal of Marketing Education, 22(1), 54-63.

48. Vander Schee, B. A.,(2010), “Active learning in the classroom: Are students engaged or amused?" Marketing Education Association Conference, The Pinnacle of Marketing Education, Seattle, USA, April, 7-9.

49. Wright, L. K., M. J. Bitner, and V. A. Zeithaml (1994), "Paradigm shifts in business education: Using active learning to deliver services marketing concepts", Journal of Marketing Education, 16(3), 5-19.

50. Wynd, W. R. (1989), “An experiential approach to marketing education”, Journal of Marketing Education, 11(Summer), 64-71.

51. Yamarik, S. (2007), “Does cooperative learning improve student learning outcomes?” Journal of Economic Education, 38(3), 259-277.

52. Young, M. R. (2002), “Experiential learning = Hands-on + Minds-on”, Marketing Education Review, $12(1), 43-51$. 


\section{APPENDIX}

\section{Comment 1}

I thought the project itself was a good assignment as it provided a way for students to apply the theory learned during the course. I liked the idea of the competition as it can be motivating for students, however I found the particular company that was chosen to be difficult for the following reasons: 1. we did not receive a lot of information upfront so to speak, 2. structure of their agreement with the University seemed to hinder some of the ideas/ recommendations the teams could have made.

\section{Comment 2}

I enjoyed the project; I didn't enjoy the client selected. I would have liked to select the company/ client and worked from there. I personally didn't find the client easy to work with, I found her interviews confusing and difficult to follow. I did like the competition part of the project, it gave an extra incentive and my group enjoyed it. Working in groups is always challenging but I think it's important and I enjoyed working with my group on this marketing plan. Down sides were having all the groups working on the same client for the project and relay the same or similar information. It was long and challenging to sit through.

\section{Comment 3}

I found that it was enjoyable to complete the project for Food Services since they may actually use some of the suggestions going forward.

\section{Comment 4}

I thought the project was very interesting and I enjoyed doing it. I think because of the short time frame of the course, it was hard to do a proper assessment of the marketing needs, but that is a time factor issue.

\section{Comment 5}

The marketing plan the class had been instructed to complete was a very good project considering the time restraints that we had to get the course and the project completed. The incentive given was a good idea to encourage the class to set forth their best efforts where they were not able to choose the business to represent for themselves. The only issue that I experienced was the limited and repetitive information that was given to the class during the interview processes. 
NOTES 